\title{
SEPASANG SUDUT ANTARA DUA OPERATOR KOMPAK DENGAN RANG HINGGA
}

\author{
Agah D. Garnadi ${ }^{1}$, Teduh Wulandari ${ }^{1}$ \\ ${ }^{1}$ Jurusan Matematika, Fakultas MIPA, Institut Pertanian Bogor, Indonesia, e-mail: \\ agah.garnadi@gmail.com, teduhw@gmail.com
}

Teruntuk Dr. Siswadi, MSc., yang memasuki usia ke 71 tahun.

\begin{abstract}
Abstrak
Dengan bantuan rumus sudut antara dua subruang, telah dirumuskan sudut antara 2 matriks berukuran sama. Karena matriks merupakan operator kompak di ruang Hilbert berdimensi hingga, dalam catatan singkat (short communication) ini, diperlihatkan rumus sudut antara 2 operator kompak dengan rank hingga di ruang Hilbert secara umum.

Kata kunci: Operator kompak rank hingga, ruang Hilbert, sudut, subruang
\end{abstract}

\begin{abstract}
A pair of angles between two matrices of the same size has been introduced with the help of angle between two subspace formula. In this short communication, as matrices is a compact operators in finite dimensional Hilbert space, we extend the notion of a pair of angles between two finite rank Compact operators in Hilbert space.
\end{abstract}

Keywords: Finite rank Compact Operator, Hilbert Space, angle, subspace

\section{Pendahuluan}

Tulisan ini, merupakan komunikasi singkat, berupa sebuah 'research announcement'.

Rumus sudut antara dua subruang di dimensi hingga [4],[5], telah dimanfaatkan untuk mendefinisikan dua sudut antara dua matriks berukuran sama [2]. Mengingat ruang hasil kali dalam berdimensi hingga merupakan ruang Hilbert, memotivasi kemungkinan perumuman apakah sudut antara dua operator linear di ruang Hilbert memiliki sifat tersebut. Tulisan ini membahas kasus khusus yang menyangkut dua operator kompak dengan rang hingga, dalam hal mana matriks merupakan hal khusus dari operator kompak.

Organisasi. Tulisan singkat ini disusun atas tiga bagian, pertama meninjau kembali hasil terdahulu, pada bagian kedua merupakan hasil utama, dan diakhiri dengan simpulan serta kerja lanjutan.

\section{Hasil Terdahulu: Sudut antara duA matriKs}

Misalkan $A, B \in R^{m, n}$ : Matriks berukuran $m \times n$.

2000 Mathematics Subject Classification: 15A60; 15A57; 15A18

Received: 01-03-2020, accepted: 06-08-2020. 
2.1. Rumus Sudut Antara Dua Subruang ([4],[5],315). Misalkan $(X,<., .>)$ adalah ruang hasil kali dalam berdimensi 2 atau lebih, $U=\operatorname{span}\left\{u_{1}, u_{2}, \cdots, u_{p}\right\}$ dan $V=\operatorname{span}\left\{v_{1}, v_{2}, \cdots, v_{q}\right\}$ adalah 2 subruang di $X$ dengan $1 \leq p \leq q<\infty$. Misalkan pula bahwa $\left\{u_{1}, u_{2}, \cdots, u_{p}\right\}$ dan $\left\{v_{1}, v_{2}, \cdots, v_{q}\right\}$ adalah ortonormal, maka $\theta$ adalah sudut antara subruang $U$ dan $V$, yang diberikan sebagai berikut.

dengan

$$
\cos ^{2}(\theta)=\operatorname{det}\left(M M^{T}\right)
$$

$$
M:=\left[<u_{i}, v_{k}>\right]=\left[u_{i}^{T} * v_{k}\right],
$$

adalah matriks berukuran $p \times q$, dan $M^{T}=\left[v_{k}^{T} * u_{i}\right]$. Perhatikan bahwa, untuk kasus $p=q$, rumus sudut menjadi:

$$
\cos (\theta)=|\operatorname{det}(M)|
$$

2.2. Dekomposisi Nilai Singular (Singular Value Decomposition, SVD)[7]. Dekomposisisi nilai singular dari matriks $A$ dan $B$, adalah [7] :

$$
\begin{aligned}
& A=U_{A} S_{A} V_{A}^{T}, U_{A} \in R^{m, p}, S_{A} \in R^{p, p}, V_{A}^{T} \in R^{p, n}, \\
& B=U_{B} S_{B} V_{B}^{T}, U_{B} \in R^{m, q}, S_{B} \in R^{q, q}, V_{B}^{T} \in R^{q, n}
\end{aligned}
$$

dengan $U_{A}, U_{B}, V_{A}$, dan $V_{B}$, merupakan matriks ortonormal. Sedangkan matriks $S_{A}$, dan $S_{B}$, merupakan matrik diagonal dengan entri diagonalnya merupakan nilai singular dari $A$ dan $B$. Perhatikan bahwa $U_{A}, U_{B}$ secara berturutan merupakan basis ortonormal ruang kolom dari $A$ dan $B$. Demikian pula dengan $V_{A}, V_{B}$ secara berturutan merupakan basis ortonormal ruang baris dari $A$ dan $B$. Selanjutnya, kita katakan dekomposisi SVD.

2.3. Pasang Sudut antara dua matriks berukuran sama. Pada [2], disampaikan hasil berikut.

2.3.1. Sudut berdasarkan representasi sudut ruang kolom. Tuliskan:

$$
U_{U A}:=U_{A}, V_{U B}=U_{B} .
$$
dihitung :

Misalkan $U_{U A}=\left[u_{1} u_{2} \cdots u_{p}\right]$ dan $V_{U B}=\left[v_{1} v_{2} \cdots v_{q}\right]$. Sudut antara $A$ dan $B$ dapat

$$
\begin{gathered}
M=\left[U_{U A}^{T} V_{U B}\right] \\
\cos ^{2}(\theta)=\operatorname{det}\left(M * M^{T}\right)
\end{gathered}
$$

2.3.2. Sudut berdasarkan representasi ruang baris. Ambil:

$$
U_{V A}:=V_{A}, V_{V B}=V_{B} .
$$

Misalkan $U_{V A}=\left[u_{1} u_{2} \cdots u_{p}\right]$ dan $V_{V B}=\left[v_{1} v_{2} \cdots v_{q}\right]$. Sudut antara $U_{V A}$ dan $V_{V B}$ dapat dihitung :

$$
\begin{gathered}
M=\left[U_{V A}^{T} V_{V B}\right] \\
\cos ^{2}(\phi)=\operatorname{det}\left(M * M^{T}\right)
\end{gathered}
$$

\section{Hasil Utama}

Misalkan $\mathcal{X}, \mathcal{Y}$ : ruang Hilbert. Misalkan $C_{1}, C_{2}: \mathcal{X} \rightarrow \mathcal{Y}$, merupakan operator kompak dengan rang hingga, yaitu dimRange $\left(C_{i}\right)<\infty$.

Pembaca dapat merujuk ke buku baku seperti Yosida[11], Kreyszig [6], maupun Wikibook untuk berbagai peristilahan terkait analisis fungsional di bagian hasil utama ini.

Karena $C_{1}$ dan $C_{2}$, berupa operator kompak, maka diperoleh SVD dari kedua operator tersebut : $[8,9]$

$$
C_{i}=\sum_{k=1}^{\infty} s_{k}^{(i)}<-, \xi_{k}^{(i)}>\eta_{k}^{(i)}, i=1,2
$$

dengan $\left\{s_{k}^{(i)}, \xi_{k}^{(i)}, \eta_{k}^{(i)}\right\}$ merupakan sistem singular dari $C_{i}$. 
Karena $C_{1}$ dan $C_{2}$ keduanya merupakan operator kompak dengan rang-hingga, maka terdapat $n_{i}, 0<n_{i}<\infty, i=1,2$, sehingga dapat dituliskan :

$$
C_{i}=\sum_{k=1}^{n_{i}} s_{k}^{(i)}<-, \xi_{k}^{(i)}>\eta_{k}^{(i)} .
$$

Pandang subruang baris (Image subspace) dari masing-masing $C_{i}$

$$
\operatorname{span}\left\{\xi_{k}^{(i)}, i=1,2,0<n_{i}<\infty\right\}=\mathcal{X}^{(i)} \subset \mathcal{X} .
$$

Karena berdimensi hingga, maka dapat dihitung matriks $M$ di rumus (2) yang berukuran $n_{1} \times n_{2}$. Maka dapat dihitung sudut $\phi$ berdasarkan rumus 5 .

Sementara dari subruang kolom (Range subspace) dari masing-masing $C_{i}$, diperoleh :

$$
\operatorname{span}\left\{\eta_{k}^{(i)}, i=1,2,0<k<=n_{i}<\infty\right\}=\mathcal{Y}^{(i)} \subset \mathcal{Y},
$$

sehingga dapat dihitung matriks $M$ di rumus (2) yang berukuran $n_{1} \times n_{2}$. Maka dapat dihitung sudut $\theta$ berdasarkan rumus 4 .

Dengan demikian, tiba di hasil utama yang dinyatakan dalam definisi berikut.

Definisi 3.1. Sudut $\theta, \phi$, secara berturutan disebut sudut kiri (subruang kolom) dan sudut kanan(subruang baris) antara dua operator kompak dengan rang hingga. Selanjutnya, pasang $(\theta, \phi)$, disebut pasang sudut antara dua operator kompak dengan rang hingga.

Contoh akan dibahas secara khusus di [3].

\section{Simpulan}

Diperlihatkan bahwa sudut antara dua operator kompak dengan rang hingga, dapat dihitung dengan mudah sesuai rumus yang digunakan untuk menghitung pasang sudut antara dua matriks berukuran sama. Sehingga definisi di ruang Hilbert berdimensi hingga, diperluas ke ruang Hilbert secara umum meskipun terbatas untuk operator Kompak di ruang Hilbert dengan rang hingga.

Dari catatan singkat ini, akan dieksplorasi untuk diaplikasikan dalam menghitung pasang sudut dari dua operator Hankel dengan rang hingga yang digunakan di bidang kontrol [9, 1], juga dimungkinkan untuk menghitung pasang sudut dari dua matriks berukuran berbeda sebagai operator kompak dengan rank hingga. Selain itu, masih terbuka apakah pasang sudut antara dua operator Kompak secara umum terdefinisikan. Ketiga topik ini, akan dibahas dikemudian hari.

\section{UCAPAN TERIMA Kasih}

Terimakasih kepada para reviewer atas masukan yang diberikan.

\section{DAFTAR Pustaka}

[1] Chu, M. T. dan Lin, M.M., 2015, On the finite rank and finite-dimensional representation of bounded semi-infinite Hankel operators, IMA Journal of Numerical Analysis, 35(3),1256-1276,

[2] Garnadi, A.D., 2019, Jarak dan Sudut antara dua matriks berdimensi sama, J. Matematika Integratif, v15 No 1 , pp 53-61

[3] Garnadi, A.D., 2020, On pair of angles between two bounded semi-infinite Hankel operators with finite rank, in preparation.

[4] Gunawan, H., Neswan, O.,2005, On Angles Between Subspaces Of Inner Product Spaces. Indonesia: Math. Society (MIHMI), Vol. 11, No. 2.

[5] Gunawan, H., Neswan, O., Setya-Budhi W., 2005, A Formula for Angles Between Two Subspaces of Inner Product Spaces, Beitrge Algebra Geom. Vol. 46(2), 311-320, 2005

[6] Kreyszig, Erwin, 1978,Introductory functional analysis with applications, wiley New York

[7] Leon, S.J., 1998, Aljabar Linear dan Aplikasinya. Edisi ke-5. A. Bondan, Penerjemah; Erlangga. Terjemahan dari Linear Algebra with Applications. 
[8] Nair, M Thamban, 2009, Linear operator equations: Approximation and regularization, World Scientific

[9] Partington, J.R., 1988, An introduction to Hankel operators, volume 13, Cambridge University Press.

[10] Wikibook, Functional Analysis, https: \\en.wikibooks.org \wiki\Functional_Analysis[diakses pada 2020]

[11] Yosida, Kösaku, 2012, Functional analysis, Springer Science \& Business Media. 